\title{
A Comparative Study on the Performance of Various Types of Loans Availed by the Farmers in Thiruvananthapuram District
}

\author{
Kshama, A.V. ${ }^{1}$ and Santha, A.M. ${ }^{2}$ \\ ${ }^{1}$ Department of Agril. Economics, College of Agriculture, Vellayani, Thiruvananthapuram, Tamil Nadu, India \\ ${ }^{2}$ Department. of Agril. Economics, College of Agriculture, Vellayani, Thiruvananthapuram, Tamil Nadu, India \\ *Corresponding author: kshama1429@gmail.com (ORCID ID: 0000-0001-5041-6731)
}

Received: 06-07-2019

Revised: $15-10-2019$

Accepted: 25-11-2019

\begin{abstract}
Agriculture is facing a scenario of shifting from subsistence farming to commercial farming. Commercial farming is more capital intensive than the subsistence farming leading to the increased credit requirement for the farmers. The main objective of the study was to investigate the performance of various kinds of credit, adequacy of credit under Kisan Credit Card scheme (KCC), cost involved in availing the credit by the KCC beneficiaries and credit requirement of the respondents. The average amount per farmer sanctioned in SBI under KCC was ₹ 69,333.33 and in case of Co-operative bank it was found to be ₹ 52,000. In case of beneficiaries the total amount sanctioned under various loans was found to be ₹ 9,67,946.93, out of which 74.11 per cent was accounted by housing loans followed by 12.53 per cent under crop loan/ KCC loan. Comparing Cost $\mathrm{A}_{2}$ with the scale of finance, credit was found to be adequate for all the crops grown by respondents. While comparing compare Cost $C$ with scale of finance, credit was found to be inadequate in tapioca only with a gap of 2.88 per cent.

Highlights

(0 The repayment was found to be more efficient in co-operative banks.

(0 The average amount sanctioned under KCC was found to be higher from the commercial bank.
\end{abstract}

Keywords: KCC, credit requirement, adequacy of credit

Kisan Credit Card Scheme (KCCs) was introduced in the year 1998-99 by NABARD and it is regarded as a land mark in the history of rural credit to address the credit needs of the resource poor farmers. The KCC aimed at providing timely and adequate credit to the farmers in a flexible, hassle free and cost effective manner. It was found that in India the total number of KCC's issued is 8.46 crores and in Kerala the total number of KCC's issued is 30.54 lakhs which accounts to 46.45 per cent of the number of operational holdings in Kerala (Samantra, 2010). Crop insurance is made mandatory under KCC and every farmer availing creditwill be covered under PMFBY. A farmer growing a notified crop under a notified area will be eligible for insurance coverage, so it acts as protection to the farmers under uncertainty condition (RBI, 2017). The shift from subsistence farming to commercial farming can be noticed in agricultural scenario. Commercial farming is more capital intensive than the subsistence farming leading to the increased credit requirement for the farmers. The main objective of the study was to investigate the performance of various kinds of credit, adequacy of credit under KCC, cost of credit to the KCC beneficiaries and credit requirement of the respondents.

How to cite this article: Kshama, A.V. and Santha, A.M. (2019). A comparative study on the performance of various types of loans availed by the farmers in Thiruvananthapuram district. Economic Affairs, 64(4): 689-694. 
Bindage et al. (2014) showed that there was inadequacy of credit for the cultivation of sugarcane crop. Bista et al. (2012) also reported that the nonKCC holder incurred more cost when compared to the KCC holders. A study by Jainuddin et al, (2015) indicated that the non-interest cost of credit was found to be higher for the respondents obtaining credit through co-operative banks as compared to the commercial banks ( $₹ 1,483$ and $₹ 1,534$ respectively). Prakash (2013) found that the noninterest cost of credit was found to be higher for the respondents of co-operative banks for taking loans under KCC when compared to the respondents of commercial banks and the respondents of RRBs did not incur any cost in availing credit under KCC. Another study by Sanjane (2010) also proved that the credit was inadequate for the crops paddy, jowar, soybean, potato and sugarcane and also concluded that the non-interest cost of credit was higher for small farmers category under KCC and non-KCC groups. A study by Sirisha (2014) found that the credit was inadequate for cultivating paddy, cotton, chilly and turmeric crops. It was also proved that the total cost of credit was found to be higher for non-beneficiaries when compared to beneficiaries.

\section{METHODOLOGY}

\section{Sampling procedure}

The study was conducted in Parassala panchayat of Neyyattinkara taluk in Thiruvananthapuram district. From this panchayat one major commercial bank and co-operative bank serving the locality was selected. From these banks 15 beneficiaries and 15 non-beneficiaries were selected at random. Thus the total sample size was 60 .

\section{Tools used}

Percentage and averages was mainly used to examine the various kinds of credit availed by the respondents viz., crop loan (KCC), general agricultural credit, vehicle loan, housing loan, agri gold loans and consumption loans. The ordinary least square estimate was applied to analyse the variables affecting the total credit requirement of the respondents.

The functional form of the model is as follows:

$$
C R=f(C, C L, N, F)
$$

Where $\mathrm{CR}=$ Credit requirement

$\mathrm{C}=$ Cost of cultivation

$\mathrm{CL}=$ Consumption loan

$\mathrm{N}=$ Loan for non-farming operations

$\mathrm{F}=$ Loan for farming operations

By taking log-linear function, the model becomes

$$
\begin{gathered}
\log C R=\log a+b_{1} \log C+b_{2} \log C L+b_{3} \log N+b_{4} \\
\log F+u
\end{gathered}
$$

Where,

$$
\begin{aligned}
& a=\text { Intercept } \\
& b_{1} \ldots . . b_{4}=\text { Regression coefficients of explanatory } \\
& \text { variables. } \\
& u=\text { Stochastic error term }
\end{aligned}
$$

\section{RESULTS}

\section{Crop loans (KCC) and General agricultural credit}

It was evident that very few non-beneficiaries of KCC applied for the general agricultural credit both in SBI and Co-operative bank. This is because the rate of interest is higher and there is no interest subvention as is in the case of KCC. This is presented in the Table 1.

The average amount sanctioned in SBI under KCC was ₹ 69,333.33 and in case of Co-operative bank it was found to be ₹ 52,000. There was complete utilization of the credit by the beneficiaries of Cooperative banks, in case of SBI 94.23 per cent of the loan amount was utilized which shows remaining 5.76 per cent of the mis-utilization of the credit. Majority of the farmers repaid the amount on time because they received an interest subvention of 3 per cent and also by this they can gain the confidence of the bankers for loans in the future. In case beneficiaries of SBI, 82.96 per cent of the loan amount was repaid and 17.04 per cent of the loan amount was overdue, whereas in case of beneficiaries of Co-operative banks 96.79 per cent of the loan amount was repaid and 3.21 per cent of the loan amount was overdue.

Under general agricultural credit only 6.6 per cent of the non-beneficiaries of KCC under Cooperative banks availed credit. The average amount sanctioned was ₹ 75,000 and the entire amount was 
Table 1: Crop loan (KCC) and the General Agricultural credit details

\begin{tabular}{llllll}
\hline \multirow{2}{*}{ S1. No. } & Particulars & \multicolumn{2}{l}{ Crop loan $(\mathrm{KCC})$} & \multicolumn{2}{l}{ General agricultural credit } \\
\cline { 3 - 6 } & $\begin{array}{l}\text { Beneficiaries } \\
\text { (SBI) }\end{array}$ & $\begin{array}{l}\text { Beneficiaries } \\
\text { (Co-operatives) }\end{array}$ & $\begin{array}{l}\text { Non-beneficiaries } \\
\text { (SBI) }\end{array}$ & $\begin{array}{l}\text { Non-beneficiaries } \\
\text { (Co-operatives) }\end{array}$ \\
\hline 1 & Number of farmers & $15(100)$ & $15(100)$ & $5(33.33)$ & $1(6.66)$ \\
2 & Avg. amount sanctioned (₹) & 69333.33 & 52000 & 60000 & 75000 \\
3 & Avg. loan amount utilized (₹) & $65333.33(94.23)$ & $52000(100)$ & $43400(72.33)$ & $75000(100)$ \\
4 & Avg. loan amount partially utilized (₹) & $4000(5.76)$ & - & $16600(27.66)$ & - \\
5 & Avg. amount repaid (₹) & $57521.33(82.96)$ & $50333.33(96.79)$ & $37600(62.66)$ & $75000(100)$ \\
6 & Avg. amount overdue (₹) & $11812(17.04)$ & $1666.67(3.21)$ & $22400(37.33)$ & - \\
7 & Actual rate of interest & 7 & & 9.25 & \\
\hline
\end{tabular}

Note: Figures in parentheses indicate percentage to total.

Table 2: Agri-gold loans taken by beneficiaries and non-beneficiaries of SBI

\begin{tabular}{llll}
\hline S1. No. & Particulars & Beneficiaries (SBI) & Non- beneficiaries (SBI) \\
\hline 1 & Number of farmers & 5 & 9 \\
2 & Avg. amount sanctioned (₹) & 75000 & 58333.33 \\
3 & Avg. loan amount utilized (₹) & $60000(80)$ & $43333.33(74.3)$ \\
4 & Avg. loan amount partially utilized (₹) & $15000(20)$ & $15000(25.7)$ \\
5 & Avg. amount repaid (₹) & $38912(51.8)$ & $31555.55(54.1)$ \\
6 & Avg. amount overdue (₹) & $36088(48.2)$ & $26777.77(45.9)$ \\
7 & Actual rate of interest & 9.25 & \\
\hline
\end{tabular}

Note: Figures in parentheses indicate percentage to total.

utilized completely and also repaid fully. In case of respondents of SBI, 33.3 per cent of them availed credit, 72.3 per cent of the loan amount was utilized and 27.7 per cent was partially utilized and 62.6 per cent of the loan amount was repaid and 37.4 per cent was left overdue.

\section{Agri-gold loans}

Some of the beneficiaries along with KCC credit has availed the agri-gold loans and the details of it is presented in Table 2 . These loans are provided only by the SBI and not the Co-operative banks because Co-operative bank provides agriculture loans only under KCC and in specific as short term loans and all other loans are considered as general loans.

The average amount sanctioned to the beneficiaries of SBI was ₹ 75,000 and for the non- beneficiaries of KCC it was ₹ 58,333.33. It was found that 80 per cent of the loan amount was utilized and 20 per cent was partially utilized and 51.8 per cent of the borrowed amount was repaid and 48.2 per cent was left overdue. In case of non-beneficiaries 74.3 per cent of the amount was utilized and 25.7 per cent of it was partially utilized and 54.1 per cent of the loan amount was repaid and 45.9 per cent was left overdue.

\section{Other types of loans}

From the Table 3. it is evident that, beneficiaries availing housing loan is higher than the vehicle loans. The consumption loan and the general gold loan was taken only by the non-beneficiaries. It can be seen that 20 per cent of beneficiaries and 33.33 per cent of non-beneficiaries availed vehicle loan. Average amount sanctioned under for the two categories was ₹ 54,250 and ₹ 56,250 respectively. Utilization of the loan was found to be 91.5 per cent in case of beneficiaries and 88.45 per cent in case of non-beneficiaries and 51.6 per cent of the loan amount was repaid by beneficiaries and nonbeneficiaries had repaid 68.3 per cent of the loan amount.

If we speak of housing loan 36.6 and 33.3 per cent of beneficiaries and non-beneficiaries respectively had availed the loan. The average amount sanctioned was found to be ₹ 71,7363.63 and ₹ 51,500 for beneficiaries and non-beneficiaries respectively. It was evident that 86.23 per cent of the loan amount 
Table 3: Other loans taken by beneficiaries and non-beneficiaries

\begin{tabular}{|c|c|c|c|c|c|c|c|}
\hline \multirow{2}{*}{$\begin{array}{l}\text { Sl. } \\
\text { No. }\end{array}$} & \multirow{2}{*}{ Particulars } & \multicolumn{2}{|l|}{ Vehicle loan } & \multicolumn{2}{|l|}{ Housing loan } & \multirow{2}{*}{$\begin{array}{l}\begin{array}{l}\text { Consumption } \\
\text { loan }\end{array} \\
\text { Non- } \\
\text { beneficiaries } \\
\end{array}$} & \multirow{2}{*}{$\begin{array}{l}\text { General gold } \\
\text { loan }\end{array}$} \\
\hline & & Beneficiaries & $\begin{array}{l}\text { Non- } \\
\text { beneficiaries }\end{array}$ & Beneficiaries & $\begin{array}{l}\text { Non- } \\
\text { beneficiaries }\end{array}$ & & \\
\hline 1 & Number of farmers & $6(20)$ & $10(33.33)$ & $11(36.66)$ & $10(33.33)$ & $3(10)$ & $1(3.33)$ \\
\hline 2 & $\begin{array}{l}\text { Avg. amount sanctioned } \\
\text { (₹) }\end{array}$ & 54250 & 56250 & 717363.63 & 515000 & 58333.33 & 55000 \\
\hline 3 & $\begin{array}{l}\text { Avg. loan amount utilized } \\
\text { (₹) }\end{array}$ & $\begin{array}{l}49666.66 \\
(91.55)\end{array}$ & $49750(88.45)$ & $618636.36(86.23)$ & $508200(98.67)$ & $32666.66(56)$ & $45000(81.81)$ \\
\hline 4 & $\begin{array}{l}\text { Avg. loan amount } \\
\text { partially utilized (₹) }\end{array}$ & $4583.33(8.44)$ & 6500 & $92318.18(12.87)$ & $6800(1.33)$ & $\begin{array}{l}15666.67 \\
(26.87)\end{array}$ & $10000(18.18)$ \\
\hline 5 & $\begin{array}{l}\text { Avg. loan amount not } \\
\text { utilized (₹) }\end{array}$ & - & - & $6409.09(0.89)$ & - & $10000(17.13)$ & - \\
\hline 6 & Avg. amount repaid $(₹)$ & $28000(51.61)$ & $38420(68.30)$ & $455590.90(63.50)$ & $339050(65.84)$ & $26133.33(44.8)$ & $55000(100)$ \\
\hline 7 & Avg. amount overdue (₹) & $26250(48.38)$ & $17830(31.69)$ & $261772.72(36.49)$ & $175950(34.16)$ & $32200(55.2)$ & - \\
\hline 8 & Actual rate of interest & 9.25 & & 8.35 & & 12 & 9 \\
\hline
\end{tabular}

utilized beneficiaries and 0.89 per cent of the credit was not-utilized. In case of non-beneficiaries 98.67 per cent of the loan amount was utilized. With regards to repayment of loan 63.5 per cent and 65.8 per cent of the loan amount was repaid by beneficiaries and non-beneficiaries respectively.

When we consider consumption loans and general gold loans, these loans were availed only by the non-beneficiaries. 10 per cent of them availed consumption loans and only 3.3 per cent availed general gold loan. The average amount sanctioned under both the loans was found to be ₹ 58,333.3 and $₹ 55,000$ respectively for consumption loan and general gold loan.

\section{Details on various types of loans}

The beneficiaries and non-beneficiaries of both the credit institutions (SBI and Co-operative bank) has taken different kinds of loans and the average amount sanctioned under each of the loans in presented in Table 4 . In case of beneficiaries the total amount sanctioned under various loans was found to be ₹ 9,67,946.93, out of which 74.11 per cent was accounted by housing loans followed by 12.53 per cent under crop loan/KCC loan, agri-gold loan and vehicle loan accounted for 7.74 and 5.62 per cent respectively. In case of beneficiaries the total amount sanctioned under different loans was found to be ₹ 8,77,916.66.

A similar trend was observed in loan availing pattern of non-beneficiaries with maximum percentage for housing loan (58.66 per cent) followed by general agricultural credit (15.37 per cent), agri-gold loan and consumption loan accounting for 6.64 per cent, vehicle loan (6.43 per cent) and general gold loan (6.26 per cent).

Table 4: Average amount sanctioned under different kinds of loans

\begin{tabular}{|c|c|c|c|}
\hline \multirow{2}{*}{$\begin{array}{l}\text { Sl. } \\
\text { No. }\end{array}$} & \multirow{2}{*}{ Particulars } & \multicolumn{2}{|c|}{$\begin{array}{l}\text { Average amount of loan } \\
\text { sanctioned (₹) }\end{array}$} \\
\hline & & Beneficiaries & $\begin{array}{l}\begin{array}{l}\text { Non- } \\
\text { beneficiaries }\end{array} \\
\end{array}$ \\
\hline 1 & Crop loan/KCC & $\begin{array}{l}1,21,333.30 \\
(12.53)\end{array}$ & - \\
\hline 2 & $\begin{array}{l}\text { General agricultural } \\
\text { credit }\end{array}$ & - & $\begin{array}{l}1,35,000.0 \\
(15.37)\end{array}$ \\
\hline 3 & Agri-gold loan & $75,000.00(7.74)$ & $58,333.33(6.64)$ \\
\hline 4 & Vehicle loan & $54,250.00(5.62)$ & $56,250.00(6.43)$ \\
\hline 5 & Housing loan & $\begin{array}{l}7,17,363.63 \\
(74.11)\end{array}$ & $\begin{array}{l}5,15,000.00 \\
(58.66)\end{array}$ \\
\hline 6 & Consumption loan & - & $58,333.33(6.64)$ \\
\hline 7 & General gold loan & - & $55,000.00(6.26)$ \\
\hline 8 & Total (₹) & $\begin{array}{l}9,67,946.93 \\
(100)\end{array}$ & $\begin{array}{l}8,77,916.66 \\
(100)\end{array}$ \\
\hline
\end{tabular}

Note: Figures in parentheses indicate percentage to total.

\section{Adequacy of the credit under KCC}

The adequacy of credit for each crop grown by the farmers was calculated and presented in the Table 5 . The scale of finance was taken by from Annexure 2-1 of the report PMFBY Rabi 1 2016-17 season (Anonymous, 2017). Scale of finance was compared at Cost $A_{2}$ and Cost $C$ for the various crops and adequacy was worked out. In order to workout 
Table 5: Adequacy of credit to the KCC beneficiaries

\begin{tabular}{|c|c|c|c|c|c|c|c|c|}
\hline \multirow{2}{*}{$\begin{array}{l}\text { Sl. } \\
\text { No. }\end{array}$} & \multirow{2}{*}{ Crop } & \multicolumn{2}{|c|}{ Avg. cost of cultivation } & \multirow{2}{*}{$\begin{array}{l}\text { Scale of } \\
\text { finance (₹/ha) }\end{array}$} & \multicolumn{2}{|c|}{ Credit gap } & \multicolumn{2}{|c|}{ Percent of credit gap } \\
\hline & & Cost $A_{2}$ & Cost C & & Cost $A_{2}$ & Cost $\mathrm{C}$ & Cost $A_{2}$ & Cost C \\
\hline 1 & Banana & 158142.4 & 278787.8 & 496100 & -337957.6 & -217312.2 & -23.03 & -14.81 \\
\hline 2 & Tapioca & 100017.7 & 179896.8 & 137500 & -37482.3 & 42396.8 & -2.55 & 2.88 \\
\hline 3 & Yard long bean & 123647.1 & 224430.2 & 290950 & -167302.9 & -66519.8 & -11.40 & -4.53 \\
\hline 4 & Cucumber & 139520.2 & 235311.0 & 290950 & -151429.7 & -55639 & -10.32 & -3.79 \\
\hline 5 & Amaranthus & 137216.9 & 226311.07 & 251680 & -114463.1 & -25368.93 & -45.47 & -1.72 \\
\hline
\end{tabular}

the adequacy of credit first we should consider the cost of cultivation of different crops at Cost $A_{2}$ and Cost $C$, then we have to deduct the scale of finance given by the district level bankers committee for that particular area. If the result obtained is negative then it indicates adequacy of credit and if positive shows inadequacy of credit. When Cost $A_{2}$ was compared with the scale of finance, for all the crops grown by respondents the credit was found to be adequate and it follows the order amaranthus (-45.47 per cent), banana (-23.03 per cent), yard long bean (-11.40 per cent), cucumber (-10.32 per cent) and tapioca (-2.55 per cent).

It was found that when we compare Cost $\mathrm{C}$ with scale of finance, only in case of tapioca the credit was found to be found inadequate with a gap of 2.88 per cent. The other crops like banana, yard long bean, cucumber and amaranthus, the credit was found to be adequate with the values -14.81 , $-4.53,-3.79$ and -1.72 per cent respectively.

\section{Cost of credit to the beneficiaries}

The cost of credit was computed for an equivalent amount of $₹ 50,000$ as loan and presented in the Table 6.

Table 6: Cost of credit for beneficiaries

\begin{tabular}{|c|c|c|c|}
\hline \multirow{2}{*}{$\begin{array}{l}\text { S1. } \\
\text { No. }\end{array}$} & \multirow{2}{*}{ Particulars } & \multicolumn{2}{|c|}{ Beneficiaries Beneficiaries } \\
\hline & & SBI & Co-operatives \\
\hline 1 & $\begin{array}{l}\text { Average amount } \\
\text { borrowed per form (₹) }\end{array}$ & 50000 & 50000 \\
\hline 2 & Travel cost (₹) & 48.27 & 46.23 \\
\hline 3 & Documentation cost (₹) & 75 & 60 \\
\hline 4 & Membership (₹) & - & 100 \\
\hline 5 & Total NIC (₹) & 123.27 & 206.23 \\
\hline 6 & Interest cost (₹) & 3500 & 3500 \\
\hline 7 & Total cost (₹) & 3623.27 & 3706.23 \\
\hline 8 & $\begin{array}{l}\text { Total cost as percent of } \\
\text { amount borrowed }(\%)\end{array}$ & 7.2 & 7.4 \\
\hline
\end{tabular}
non interest cost and it was worked out to 7.2 and 7.4 per cent respectively for beneficiaries of SBI and Co-operatives. Eventhough the rate of interest was the same for beneficiaries and non-beneficiaries. The total Non-Interest cost (NIC) for the beneficiaries of SBI was ₹ 123.27 and that of the Co-operative was ₹ 206.23 which included the membership fees of $₹ 100$ for the lifetime.

\section{Credit requirement of the respondents}

In order to know the credit requirements of the farmers ordinary least square estimates was performed. The credit requirement was considered as the dependent variable wherein the amount of credit required by the farmers for different purposes was taken and other variables like cost of cultivation incurred in growing different crops by the respondents, amount of consumption loan taken, loan for farming operations (KCC credit, general agricultural credit and agri-gold loans) and loan for non-farming operations (vehicle loan, housing loan, consumption loan and general gold loan) were considered as the independent variables. It presented is in Table 7.

Table 7: Credit requirements of the respondents

\begin{tabular}{|c|c|c|c|c|}
\hline $\begin{array}{l}\text { Sl. } \\
\text { No. }\end{array}$ & Variable & Coefficient & $\begin{array}{l}\text { Standard } \\
\text { error }\end{array}$ & t-value \\
\hline 1 & Intercept & 11.13 & 2.92 & 3.81 \\
\hline 2 & Cost of cultivation & $0.33^{*}$ & 0.24 & 7.51 \\
\hline 3 & Consumption loan & 0.34 & 0.12 & 3.11 \\
\hline 4 & $\begin{array}{l}\text { Loan for farming } \\
\text { operations }\end{array}$ & 0.32 & 0.05 & 5.87 \\
\hline 5 & $\begin{array}{l}\text { Loan for non-farming } \\
\text { operations }\end{array}$ & $0.36^{*}$ & 0.03 & 10.8 \\
\hline
\end{tabular}

From the table it is evident that cost of cultivation and loan for non-farming operations was found 
$\underset{\text { AESRA }}{\text { SI }}$

to be significant at 5 per cent level of significance and are influencing the credit requirement of the respondents positively. The $\mathrm{t}$-values for all the variables was found to be significant. The coefficient of multiple determination $\left(\mathrm{R}^{2}\right)$ was found to be 0.86 , which means 86 per cent of the credit requirement is explained by the variables considered in the model. Hence it was found that cost of cultivation and non-farming operations influence more on the credit requirement of the respondents.

\section{CONCLUSION}

The average amount sanctioned under KCC was found to be higher from the commercial bank (SBI) when compared to co-operative bank, but when it comes to repayment beneficiaries of cooperatives were more prompt at repayment with very less amount of overdue. When different loans were compared it was found that there is higher need for consumption loan compared to the production credit. At Cost $\mathrm{A}_{2}$ the credit was found to be adequate for all the crops. At Cost $\mathrm{C}$, credit was found to be adequate for all the crops grown by respondents except for tapioca. The total cost of credit was found to be higher for beneficiaries of Co-operative bank (7.4 per cent) compared to beneficiaries of SBI (7.2 per cent). The analysis showed that cost of cultivation and loan for nonfarming operations were found to be influencing the credit requirement of the respondents positively. It implies that as the cost of cultivation increases there is tendency of farmers to obtain more credit and the non-farm loan are indicative of more consumption credit by the respondents. Eventhough the study revealed the adequacy of credit provided under $\mathrm{KCC}$, there is a scope for the expansion of credit for the various needs of the farming community.

\section{REFERENCES}

[Anonymous]. 2017. PMFBY Rabi 1 2016-17 Season. Available: http://www.keralaagriculture.gov.in/pdf/bid_doc_ RWBCIS_II\%20(1).pdf [05 Dec. 2017].

Bindage, A.B., Patel, R.R., Makani, R.M., Sante, P.R. and Raut, V.P. 2014. Economic evaluation of Kisan Credit Card scheme for sugarcane crop in Kolhapur district of Maharastra. Karnataka J. Agril. Sci., 27(3): 360-362.

Bista, D.R., Kumar, P. and Mathur, V.C. 2012. Progress and Performance of KCC scheme with case study. Agric. Econ. Res. Rev., 25(1): 125-135.

Jainuddin, S.M., Hiremath, G.M. and Patil, S.S. 2015. Efficiency of Kisan credit card scheme in Karnataka: A comparative study of commercial and cooperative banks. Agric. Econ. Res. Rev., 28(2): 351-357.

Prakash, P. 2013. Impact of Kisan Credit Card on farm income: A case study of Krishnagiri district of Tamil Nadu. M.Sc. (Ag) thesis, Indian Agricultural Research Institute, New Delhi, pp. 79.

RBI [Reserve Bank of India]. 2017. RBI home page [on line]. Available: http://www.rbi.org.in [17 Aug. 2017].

Sajane, A.M. 2010. An economic evaluation of Kisan Credit Card scheme in Belgaum district of Karnataka and Sangli district of Maharashtra. M.Sc. (Ag) thesis, University of Agricultural Sciences, Dharwad, pp. 90.

Samantra, R.S. 2010. Kisan credit card - A study [book on-line]. Dept. of Economic Analysis and Research. NABARD. Available:http://www.nabard.org/pdf/ Kisan\%20Credit20\%Card.pdf. [8 Nov 2016]

Sirisha, K.V.J.K. 2014. Performance evaluation of Kisan Credit Card scheme in Guntur district of Andhra Pradesh. M.Sc. (Ag) thesis, Acharya N.G.Ranga Agricultural University, Hyderabad, pp. 105. 